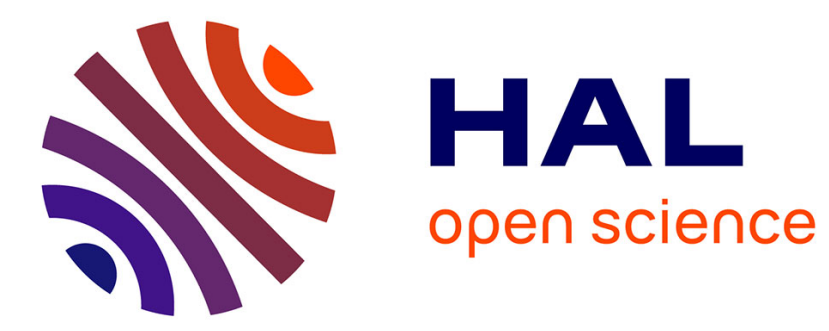

\title{
Spectrophotometric study of cobalt(II) chloride complexes in ethanol and propan-2-ol.
}

\author{
S. Lechat, Mustayeen A. Khan, G. Bouet., Vierling F.
}

\section{To cite this version:}

S. Lechat, Mustayeen A. Khan, G. Bouet., Vierling F.. Spectrophotometric study of cobalt(II) chloride complexes in ethanol and propan-2-ol.. Inorganica Chimica Acta, 1993, 211, pp.33-36. 10.1016/S00201693(00)82840-6 . hal-03175690

\section{HAL Id: hal-03175690 \\ https://univ-angers.hal.science/hal-03175690}

Submitted on 22 Mar 2021

HAL is a multi-disciplinary open access archive for the deposit and dissemination of scientific research documents, whether they are published or not. The documents may come from teaching and research institutions in France or abroad, or from public or private research centers.
L'archive ouverte pluridisciplinaire HAL, est destinée au dépôt et à la diffusion de documents scientifiques de niveau recherche, publiés ou non, émanant des établissements d'enseignement et de recherche français ou étrangers, des laboratoires publics ou privés. 


\title{
Spectrophotometric study of cobalt(II) chloride complexes in ethanol and propan-2-ol
}

\author{
S. Lechat, M.A. Khan* and G. Bouet \\ Laboratoire de Chimie de Coordination, Faculté de Pharmacie, 16 Boulevard Daviers, F-49100 Angers (France) \\ F. Vierling \\ Laboratoire de Chimie Physique, EHICS, URA CNRS No. 405, Université Louis Pasteur, 1 Rue Blaise Pascal, F-67008 Strasbourg- \\ Cedex (France)
}

(Received February 8, 1993; revised June 8, 1993)

\begin{abstract}
A spectrophotometric investigation of cobalt(II) chloro complexes was carried out in ethanol and propan-2-ol at $25{ }^{\circ} \mathrm{C}$ and at constant ionic strength of $1 \mathrm{~mol}^{-1}$. Three mononuclear complexes are identified in both the solvents: $\mathrm{CoCl}^{+}, \mathrm{CoCl}_{2}$ and $\mathrm{CoCl}_{3}{ }^{-}$and the respective apparent overall stability constants are calculated. The calculated values in ethanol are: $\log \beta_{1}=1.3, \log \beta_{2}=2.8, \log \beta_{3}=4.1$; in propan-2-ol: $\log \beta_{1}=1.7, \log \beta_{2}=3.3$, $\log \beta_{3}=4.7$. Stability is higher in the higher alcohol. Individual electronic spectra of all species in both the solvents are calculated and reported here for the first time.
\end{abstract}

\section{Introduction}

The colour change of cobalt(II) chloride solutions from pink to blue is well known and numerous qualitative studies of this phenomenon are widely used to demonstrate the principle of Le Chatelier. We cite here only some of the recent studies on the qualitative aspects of this system [1-3].

Quantitative investigations were undertaken by Katzin and Gebert in solution [4] and in the solid state [5], who reported the presence of two complexes in solution: the di- and the trichloro complex with the possibility of the presence of the tetrachloro complex in solution of excess chloride concentration. They assigned different bands to specific complexes and concluded that various blue forms have tetrahedral groupings. Identical complexes but with different absorption bands assigned to them have been reported by Fine [6] who also calculated their stepwise formation constants. Cotton et al. [7] studied $\mathrm{Co}(\mathrm{OH})_{2}$ in concentrated alkali metal hydroxides concluding that $\left[\mathrm{CoX}_{4}\right]^{2-}$ ions are not obtained, or only partially obtained, in aqueous solutions of cobalt(II), even when saturated with $\mathrm{HX}$ or $\mathrm{LiX}(\mathrm{X}=\mathrm{Cl}$, $\mathrm{Br}, \mathrm{I})$. Trutia and Musa [8] have shown that $\mathrm{Co}^{2+}$ is tetrahedrally coordinated in ethanol, and in methanol Bkouche-Waksman correlates polarisation properties in terms of stability of compounds of the form $\mathrm{CoCl}_{2}$ [9].

*Author to whom correspondence should be addressed.
Benali-Baitich and coworkers [10] have studied in detail the chloro complexes of transition metals in perchloric acid aqueous medium and report four species: $\left\{\mathrm{Co}\left(\mathrm{H}_{2} \mathrm{O}\right)_{6}{ }^{2+}, \mathrm{Cl}^{-}, \mathrm{Co}\left(\mathrm{H}_{2} \mathrm{O}\right)_{6}{ }^{2+}\right\}$ absorbing at $340 \mathrm{~nm}$, $\left\{\mathrm{Co}\left(\mathrm{H}_{2} \mathrm{O}\right)_{6}{ }^{2+}\right\}$ absorbing at 360 and $315 \mathrm{~nm},\left[\mathrm{Co}\left(\mathrm{H}_{2} \mathrm{O}\right)_{5}\right.$ $\mathrm{Cl}^{+}$with absorption bands at 530, 480, 250 and 208 $\mathrm{nm}$, and $\left[\mathrm{CoCl}_{4}\right]^{2-}$ which absorbs at 690,665 and 625 $\mathrm{nm}$. They calculated the formation constant of the first complex, whose value is quite different from that calculated by Fine. They also indicate that $\left[\mathrm{CoCl}_{4}\right]^{2-}$ formed in solution does not exceed $2.5 \%$, even in concentrated solutions. Zeltmann et al. [11] have also postulated, in addition to the hexaaqua ion, four complexes viz. $\left[\mathrm{Co}\left(\mathrm{H}_{2} \mathrm{O}\right)_{5} \mathrm{Cl}\right]^{+}, \quad\left[\mathrm{Co}\left(\mathrm{H}_{2} \mathrm{O}\right)_{2} \mathrm{Cl}_{2}\right]$, $\left[\mathrm{Co}\left(\mathrm{H}_{2} \mathrm{O}\right) \mathrm{Cl}_{3}\right]^{-}$and $\left[\mathrm{CoCl}_{4}\right]^{2-}$ in hydrochloric acid solutions up to 16 molality. Bjerum and coworkers [12, 13] studied this system in strong aqueous chloride solutions, identifying four cobalto complexes and calculated the stability constants. For the first complex their value of $\log K_{1}=1.34$ is nearly the same as calculated by us in ethanol. On the other hand, Licheri et al. [14] in an X-ray diffraction study of $\mathrm{MeCl}_{2}$ solutions $(\mathrm{Me}=\mathrm{Co}, \mathrm{Ni})$ characterise only the complex $\left[\mathrm{Me}\left(\mathrm{H}_{2} \mathrm{O}\right)_{5} \mathrm{Cl}\right]^{+}$with the possible presence of higher complexes.

We have already reported the results of chloro complexes of copper(II) in different protic and aprotic solvents and more recently in a specific class of solvents 
such as alcohols [15-18]. In this paper, we present the results of cobalt(II) chloro complexes in ethanol and propan-2-ol at constant ionic strength of $1 \mathrm{~mol}^{-1}$ and at $25^{\circ} \mathrm{C}$. Apparent overall stability constants, $\beta_{j}$, have been calculated for the equilibrium

$$
\begin{aligned}
& \mathrm{Co}^{2+}+\mathrm{jll}^{-} \rightleftharpoons \mathrm{CoCl}_{j}^{(j-2)-} \\
& \beta_{j}=\frac{\left[\mathrm{CoCl}_{j}^{(j-2)-}\right]}{\left[\mathrm{Co}^{2+}\right][\mathrm{Cl}-]^{j}}
\end{aligned}
$$

from a spectrophotometric study in the UV and visible region.

Although this solution equilibrium has already been studied before, this work presents a first quantitative attempt at determining the stability constants as well as the electronic spectra of all species present in solution. The complexes have been studied specifically in alcoholic medium with a view to compare, eventually, their stability and spectra with those of the copper(II) and nickel(II) chloride complexes. The latter are under investigation in our laboratory whereas we have already reported the results of copper(II) chloro complexes. These complexes especially in the alcohols are actually been studied in medical circles in connection with Wilson's disease concerning the fixation of copper in
liver.

\section{Experimental}

Ethanol and propan-2-ol pro analysis (Merck) were used without further treatment. Stock solutions of salts were prepared from $\mathrm{LiCl}, \mathrm{LiClO}_{4}$ and $\mathrm{Co}\left(\mathrm{ClO}_{4}\right)_{2} \cdot 6 \mathrm{H}_{2} \mathrm{O}$, all Fluka, p.a. products and the preparation of mixtures was carried out by dilution. The presence of a small amount of water due to cobalt perchlorate hexahydrate has no appreciable effect on the absorption spectra. The absorption variations were measured with a Beckman UV 5230 spectrophotometer and the spectrophotometric reference solution was $1 \mathrm{~mol} \mathrm{l}^{-1} \mathrm{LiClO}_{4}$ in ethanol and in propan-2-ol. The analytical concentration of the metal with respect to that of the ligand was kept very low and the possibility of the formation of polynuclear complexes is thus neglected. The final analytical concentration of cobalt was fixed at $5 \times 10^{-3}$ $\mathrm{mol} 1^{-1}$, that of ligand varied from $2.5 \times 10^{-4}$ to 1.0 mol $1^{-1}$. The numerical calculations based on leastsquares method were carried out on an IBM 3090 computer at the Université Louis Pasteur, Strasbourg.

\section{Results and discussion}

The experimental spectra of the cobalt(II) chloride 1 and 2, respectively.
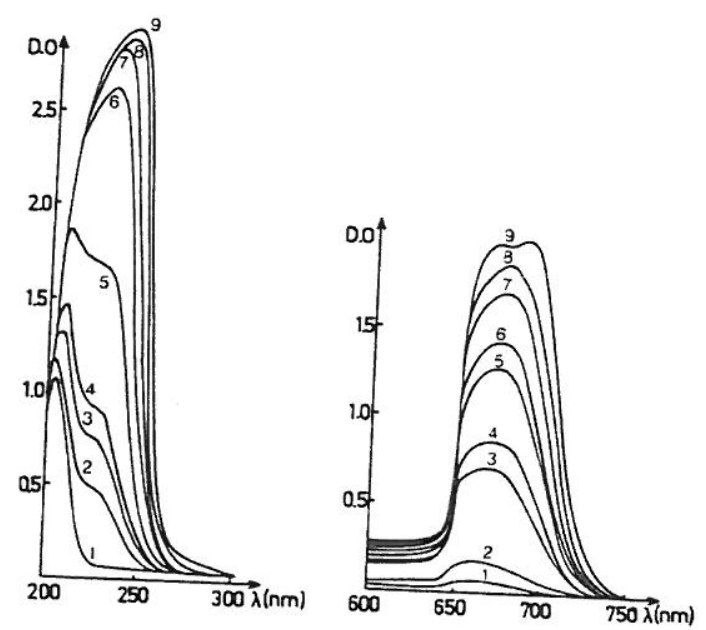

Fig. 1. Absorption spectra of cobalt(II)- $\mathrm{Li}^{+}\left(\mathrm{CL}^{-}, \mathrm{ClO}_{4}^{-}\right) 1 \mathrm{M}$ solutions in ethanol: [Co $\left.{ }^{\mathrm{II}}\right]=5 \times 10^{-3} \mathrm{~mol} \mathrm{l} \mathrm{I}^{-1}, \mathrm{I}_{\text {cuve }}=1 \mathrm{~cm}$. $\left[\mathrm{Cl}^{-}\right]$ $0.03 ; 7,0.04 ; 8,0.08 ; 0 ; 2,0.005 ; 3,0.008 ; 4,0.01 ; 5,0.02 ; 6$, $4,0.05 ; 5,0.08 ; 6,0.1 ; 7,0.2 ; 8,0.6$ visible: $1,0.01 ; 2,0.02 ; 3,0.04$;
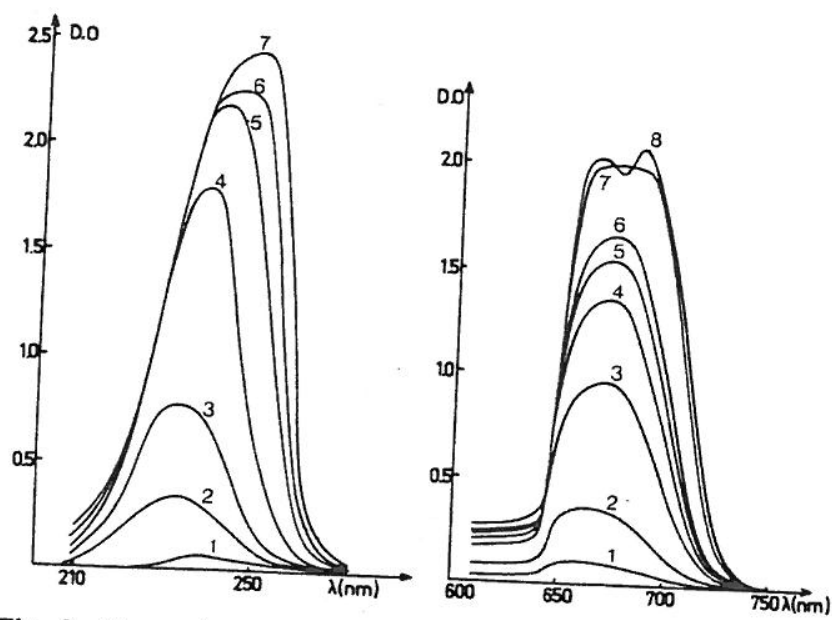

Fig. 2. Absorption spectra of cobalt(II)- $\mathrm{Li}^{+}\left(\mathrm{Cl}^{-}, \mathrm{ClO}_{4}^{-}\right) 1 \mathrm{M}$ solutions in propan-2-ol: $\left[\mathrm{Co}^{\mathrm{II}}\right]=5 \times 10^{-3} \mathrm{~mol} \mathrm{l}^{-1}, \mathrm{l}_{\text {cuve }}=1 \mathrm{~cm}$. $\left[\mathrm{Cl}^{-}\right],\left(\mathrm{mol} \mathrm{l} 1^{-1}\right):($ a) UV: $1,0.001 ; 2,0.005 ; 3,0.01 ; 4,0.02 ; 5$, $5,0.08 ; 6,0.1 ; 7,0.4 ; 8,0.8$. $1,0.01 ; 2,0.02 ; 3,0.04 ; 4,0.06$;

In ethanolic solutions the maximum absorption band of cobalt(II) is located at $210 \mathrm{~nm}$. With the addition of ligand a shoulder peak is formed at about $240 \mathrm{~nm}$ and both these maxima fuse into one asymmetric absorption band undergoing a bathochromic shift up to $255 \mathrm{~nm}$. In the visible region the $660 \mathrm{~nm}$ absorption of the solvated cobalt(II) ion increases in intensity with increasing ligand concentration finally splitting, for $C=1.0 \mathrm{~mol} \mathrm{l}^{-1}$, into two bands at 665 and $695 \mathrm{~nm}$.

The propanolic solutions exhibit nearly the same evolution in the visible spectrum. In the UV range, however, there appears an intense band at $235 \mathrm{~nm}$, displaced up to $250 \mathrm{~nm}$ for higher ligand concentrations. 
A matrix rank treatment method was used to determine the minimum number of species present in the solution [19] which requires a set of $N \times L$ data where $N$ is the number of solutions and $L$ the number of wavelengths. The result of this analysis indicated the presence of at least three complexes in both the solvents - ethanol and propan-2-ol. The theoretical expressions and the mathematical treatment have been given in our earlier publications $[20,21]$.

The numerical treatment was carried out on the $\{1$, $2,3\}$ and the $\{1,2,3,4\}$ models, i.e. models with three and four successive mononuclear complexes. The best results, summarized in Table 1, were obtained for models with three complexes and it is observed that the stabilities of these complexes are higher in propan-2-ol than in ethanol. It is quite probable that the stability of the cobalto complexes increases with the number of atoms of carbon in the alcohol as is the case with the corresponding copper complexes which we have described earlier [18].

The absence of the fourth complex, $\left[\mathrm{CoCl}_{4}\right]^{2-}$, is notable. The tetracoordinated complex is always formed in appreciable quantities in all solvents in copper solutions but with cobalt as the central metal ion this does not seem to be the case. Although the formation of the tetrachloro cobaltate has been reported by different authors, Cotton et al. think that $\left[\mathrm{CoX}_{4}\right]^{2-}$ ions are hardly obtained in aqueous solutions and for BenaliBaitich even in concentrated solutions the formation of $\left[\mathrm{CoCl}_{4}\right]^{2-}$ does not exceed $2.5 \%$. We believe that in this system, the fourth complex may be formed in significant quantities only in some aprotic organic solvents at higher concentrations of cobalt [22].

The stability constants determined earlier were used to calculate the electronic spectra of the three complexes in the two alcohols. Figures 3 and 4 show these spectra in ethanol and propan-2-ol, respectively, and Table 2 summarizes the characteristic absorption bands of each complex in the two solvents.

The distribution curves for the complexes in the two solvents follow identical patterns and are represented by the curves in ethanol, Fig. 5 . It can be noted that whatever the concentration, there is always the simultaneous presence of at least two species.

TABLE 1. Overall stability constants of the cobalt(II) chloride complexes in ethanol and propan-2-ol

\begin{tabular}{lll}
\hline Constant & \multicolumn{2}{l}{ Solvent } \\
\cline { 2 - 3 } & Ethanol & Propan-2-ol \\
\hline$\beta_{1}\left(\log \beta_{1}\right)$ & $20(1.3)$ & $50(1.7)$ \\
$\beta_{2}\left(\log \beta_{2}\right)$ & $570(2.8)$ & $1.8 \times 10^{3}(3.3)$ \\
$\beta_{3}\left(\log \beta_{3}\right)$ & $1.2 \times 10^{4}(4.1)$ & $4.5 \times 10^{4}(4.7)$ \\
$\sigma$ UV-Vis & 0.095 & 0.080 \\
\hline
\end{tabular}
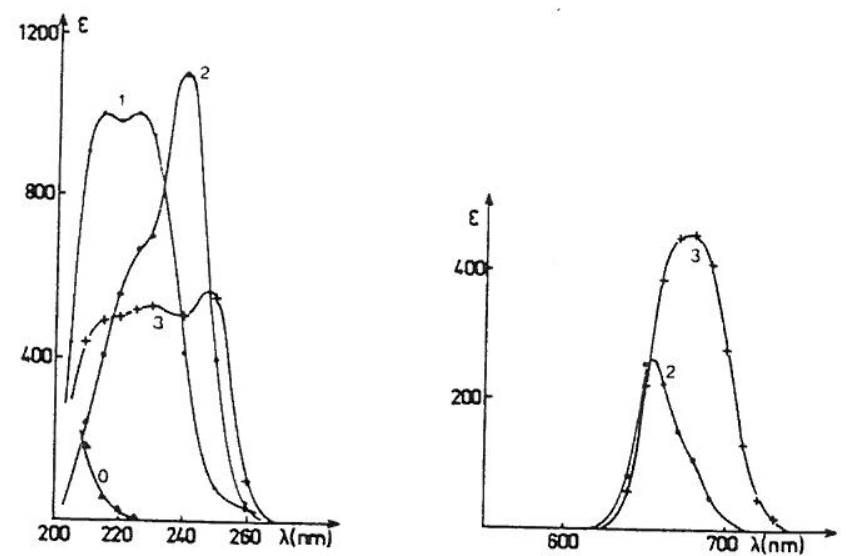

Fig. 3. Calculated electronic spectra of cobalt(II) chloro complexes in ethanol: $0, \mathrm{Co}^{2+} ; 1, \mathrm{CoCl}^{+} ; 2, \mathrm{CoCl}_{2} ; 3, \mathrm{CoCl}_{3}{ }^{-}$.
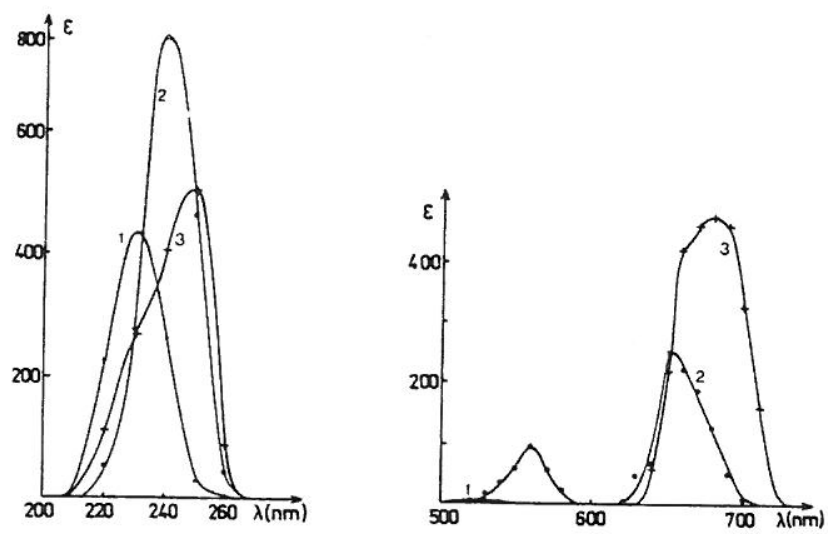

Fig. 4. Calculated electronic spectra of cobalt(II) chloro complexes in propan-2-ol: $1, \mathrm{CoCl}^{+} ; 2, \mathrm{CoCl}_{2} ; 3, \mathrm{CoCl}_{3}{ }^{-}$.

TABLE 2. Characteristic absorption bands of the three complexes in the two solvents ${ }^{\mathrm{a}}$

\begin{tabular}{lll}
\hline Complex & Solvent & \\
\cline { 2 - 3 } & $\begin{array}{l}\text { Ethanol } \\
\lambda_{\max }(\mathrm{nm}) \\
\left(\epsilon_{\max }\left(1 \mathrm{~mol} \mathrm{~m}^{-1} \mathrm{~cm}^{-1}\right)\right)\end{array}$ & $\begin{array}{l}\text { Propan-2-ol } \\
\lambda_{\max }(\mathrm{nm}) \\
\left(\epsilon_{\max }\left(1 \mathrm{~mol}^{-1} \mathrm{~cm}^{-1}\right)\right)\end{array}$ \\
\hline $\mathrm{CoCl}^{+}$ & $215(1000)$ & \\
& $226(1000)$ & $230(435)$ \\
$\mathrm{CoCl}_{2}$ & $225 \mathrm{sh}$ & $510(15)$ \\
& $240(1180)$ & $240(805)$ \\
& $652(260)$ & $560(95)$ \\
$\mathrm{COCl}_{3}{ }^{-}$ & $213 \mathrm{sh}$ & $652(255)$ \\
& $238(428)$ & $230 \mathrm{sh}$ \\
& $248(568)$ & $249(510)$ \\
& $675(455)$ & $660 \mathrm{sh}(420)$ \\
& & $680(475)$ \\
\hline
\end{tabular}

"sh $=$ shoulder peak. 


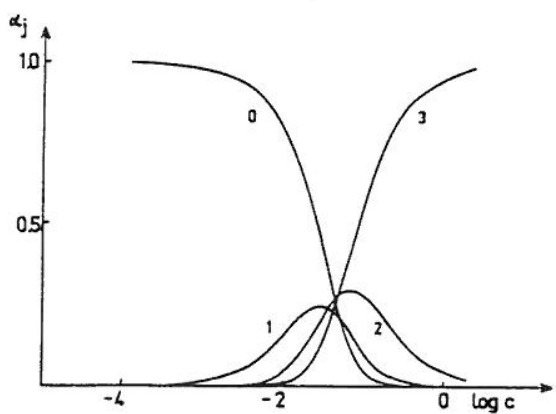

Fig. 5. Formation curves of chloro complexes of cobalt(II) in ethanolic solutions ( $\alpha=$ degree of formation; $c=$ free ligand concentration): $0, \mathrm{Co}^{2+} ; 1, \mathrm{CoCl}^{+} ; 2, \mathrm{CoCl}_{2} ; 3, \mathrm{CoCl}_{3}{ }^{-}$.

The characteristic absorption maxima for $\mathrm{CoCl}^{+}$ $(228 \pm 2 \mathrm{~nm}), \mathrm{CoCl}_{2}(240$ and $652 \mathrm{~nm})$ and $\mathrm{CoCl}_{3}{ }^{-}$ (248 and 675-680 $\mathrm{nm}$ ) are identified in ethanol as well as in propanol. It is very interesting to notice that in the UV region there is always one absorption band more in ethanol than in propanol whereas in the visible region it is in propanol that there is always one maximum of absorption more than in the lighter alcohol. The investigation of this system in methanol could throw more light on this strange behaviour and at the same time give an idea on the evolution of stabilities of these complexes in alcoholic media.

\section{References}

1 L. Gene Spears and Larry G. Spears, J. Chem. Educ., 61 (1984) 252
2 L.J.A. Martins and J.B. Da Costa, J. Chem. Educ., 63 (1986) 989.

3 S. Cronier, Doctoral Thesis in Pharmacy, University of Angers, France, 1992.

4 L.I. Katzin and E. Gebert, J. Am. Chem. Soc., 72 (1950) 5464.

5 L.I. Katzin, J. Am. Chem. Soc., 76 (1954) 3089.

6 D.A. Fine, J. Am. Chem. Soc., 84 (1962) 1140.

7 F.A. Cotton, D.M.L. Goodgame and M. Goodgame, J. Am. Chem. Soc., 83 (1961) 4690.

8 A. Trutia and M. Musa, Rev. Roum. Chim., 11 (1966) 92.

9 I. Bkouche-Waksman, Bull. Soc. Chim. Fr. (1968) 3510.

10 E. Wendling, O. Benali-Baïtich and G. Yaker, Rev. Chim. Miner., 8 (1971) 559.

11 A.H. Zeltmann, N.A. Tiatwiyoff and L.O. Morgan, J. Phys. Chem., 72 (1968) 121.

12 J. Bjerum, A.S. Halonin and L.H. Skibsted, Acta Chem. Scand., Ser. A, 29 (1975) 326.

13 L.H. Skibsted and J. Bjerum, Acta Chem. Scand., Ser. A, 32 (1978) 429.

14 G. Licheri, G. Paschina, G. Piccaluga and G. Pinna, J. Chem. Phys., 79 (1983) 2168.

15 M.A. Khan, J. Meullemestre, M.J. Schwing and F. Vierling, Inorg. Chem., 28 (1989) 3306.

16 S. Chafaa, T. Douadi, M.A. Khan, J. Meullemestre, M.J. Schwing and F. Vierling, New J. Chem., 15 (1991) 39.

17 S. Dali, F. Bengahem, M.A. Khan, J. Meullemestre and F. Vierling, Polyhedron, 10 (1991) 2529.

18 E. Bentouhami, M.A. Khan, J. Meullemestre and F. Vierling, Polyhedron, 11 (17) (1992) 2179.

19 Z.Z. Hugus and A.A. El Awady, J. Phys. Chem., 75 (1971) 2954.

20 M. Elleb, J. Meullemestre, M.J. Schwing and F. Vierling, Inorg. Chem., 19 (1980) 2699.

21 F. Vierling, M.J. Schwing and J. Meullemestre, Spectra 2000, 79 (1982) 10.

22 A. Chiboub-Fellah, J. Meullemestre, M.J. Schwing and F. Vierling, Inorg. Chem., submitted for publication. 